\title{
KONSERVASI ALAM DALAM PERSPEKTIF ETIKA ISLAM; TANTANGAN DAN TUNTUTAN GLOBALISASI
}

\author{
Abd. Aziz*
}

\begin{abstract}
As a part of environment, people should keep the perpetuation, the balance, and the beauty of nature. A smart use of limited natural resources must be a slogan in daily life. This environment is not provided only for human, but also for other creatures. Factually, many people damage universe by illegal logging, free mining, uncontrolled drilling, of course, without any analysis of its damage impact to the environment. After discussing these problems through an approachment of environment ethics; Anthroposentrism, Biocentrism, Ecocentrism, Eco-feminism, this articel found that the cause of the damage of this universe is a transcendental paradigm factor assumed that conservation was not emphasized by Islam. Through these conservational paradigm; ecology, environment figh, and eco-sufism, in term of universe utilization, people should balanced three amanah aspects; al-intifấ, al-i'tibâr, dan al-ishlâh. These three environment ethics not just investigated the way of people behavior to universe, but also the relation among creatures in this universe, between people and people, people and all other creatures.
\end{abstract}

Keywords: conservation, ecology, environment figh, eco-sufism

* Dosen sekaligus Rektor Institut Ilmu Keislaman Zainul Hasan Genggong (abdulaziz-inzah@yahoo.com) 


\section{PENDAHULUAN}

Krisis lingkungan telah disadari sebagai problem terbesar abad ini. Ini disebabkan karena pencemaran lingkungan merupakan isu global yang dampaknya menimpa penghuni dunia masa kini dan generasi mendatang. ${ }^{1}$ Bukan hanya pencemaran lingkungan saja akan tetapi krisis ekologi secara umum sangat menyita konsentrasi para tokoh untuk mencari formula solusi dengan keyakinan bahwa persoalan ekologi tidak hanya bisa diselesaikan secara parsial. Sampai pada rumusan penyelesaian bahwa persoalan ekologi sangat membutuhkan sentuhan etik. Hal ini terbukti dengan dimasukkannya krisis ekologi dalam isu global etik.

Ekologi sebagai sebuah kajian telah melahirkan berbagai teori tentang lingkungan, diantaranya adalah antroposentis, biosentris, ekosentris, ekofeminis dan hak asasi alam. Teori-teori tersebut, dalam prakteknya telah melahirkan perilaku etis sesuai dengan coraknya masing-masing. Namun demikian, teori tersebut tidak kunjung mampu menyelesaikan kompleksitas persoalan lingkungan yang ada. Bahkan ada diantara teori tersebut yang pada akhirnya mengkhawatirkan keberlangsungan lingkungan hidup.

Bukti real yang dapat dijadikan fakta bahwa krisis lingkungan sudah begitu kritis adalah data yang dilansir oleh World Wide Fund for Nature $(\mathrm{WWF})^{2}$ bahwa Indonesia merupakan negara pemilik hutan hujan tropis terluas ke-3 sedunia setelah Brazil dan Kongo dengan luas hutan sekitar 109 juta hektar (2003). Akan tetapi, dari luasan hutan yang tersisa itu, hampir setengahnya terdegradasi. Namun tak banyak yang menyadari bahwa kekayaan hutan Indonesia tidaklah sebatas kayu. Keanekaragaman flora dan fauna ini sangat bermanfaat, diantaranya bagi industri farmasi/kerajinan, pariwisata, dan ilmu pengetahuan.

1 Alwi Shihab, Islam Inklusif, Menuju Sikap Terbuka dalam Beragama, (Jakarta: Penerbit Mizan, 1999), h. 157.

2 World Wide Fund for Nature(WWF) adalah sebuah organisasi nonpemerintahinternasional yang menangani masalah-masalah tentang konservasi, penelitian dan restorasilingkungan, dulunya bernama World Wild Life Fund dan masih menjadi nama resmi di Kanada dan Amerika Serikat. WWF adalah organisasi konservasi independen terbesar di dunia dengan lebih dari 5 juta pendukung di seluruh dunia yang bekerja di lebih dari 100 negara, mendukung sekitar 1.300 proyek konservasi dan lingkungan. http://www.wwf.or.id/tentang_wwf/whoweare. 
Disamping itu, hutan juga menjaga fungsi tata air, menyerap dan menyimpan karbondioksida, serta sumber air bagi kebutuhan makhluk hidup. Sejak tahun 1970 penggundulan hutan mulai marak di Indonesia. Pada tahun 1997-2000, laju kehilangan dan kerusakan hutan Indonesia mencapai 2,8 juta hektar/tahun. Saat ini diperkirakan luas hutan alam yang tersisa hanya $28 \%$. Jika tidak segera dihentikan, maka hutan yang tersisa akan segera musnah. ${ }^{3}$ Data lain yang menunjukkan krisis hutan adalah ketika Indonesia menjadi negara penghancur hutan tercepat di dunia pada tahun 2008. Sekitar 2\% dari total hutan dunia yaitu 1.871 juta hektar atau rata-rata 51 kilometer hutan rusak antara tahun 2000 . 2005 setiap tahun. ${ }^{4}$

Krisis lingkungan telah disadari sebagai problem terbesar abad ini. Para ahli telah memetakan bahwa krisis lingkungan telah menyebabkan bencana-bencana, perubahan iklim, pemanasan global, menyusutnya kualitas hidup dan ancaman kehancuran bumi di masa depan. Karena itu manusia sejagat terus mencari solusi bersama guna mengatasi laju percepatan krisis. Kemampuan teknologi, analisis-analisis geografi dan iklim terus dipakai sebagai cara menemukan solusi yang efektif untuk mengatai krisis lingkungan. Selain itu, peratuan, undangundang, traktak-traktak tentang konservasi dan kemauan politik juga ditempuh untuk mengefektifkan pelaksanaan penanggulangan krisis. Namun demikian, para ahli merasa semua piranti itu belumlah cukup, mereka mengamati dengan cermat bahwa ada persoalan mendasar yang menyebabkan manusia sebagai penyebab kerusakan lingkungan tersebut yakni tentang aspek spiritualitas manusia. ${ }^{5}$

Islam sebagai agama yang sempurna tentunya mempunyai dasardasar ajaran untuk umatnya yang berelasi dengan lingkungan. Di dalam rujukan utama Islam (al-Qur'an dan al-sunnah), telah ada ajaran yang jelas tentang pentingnya pelestarian lingkungan. Sekalipun belum terperinci, rujukan tersebut dapat dijadikan dasar untuk memformulasikan konsep ekologi yang Islami. Oleh karena itu, menjadi

3 http://www.wwf.or.id/tentang_wwf/whoweare

4 Sudarsono, Bumiku Semakin Panas, (Yogyakarta: PPLHRJ, 2008), h. 129.

5 Mudhofir Abdullah, Argumentasi Konservasi Lingkungan dalam Perspektif Ekoteologi, dalam Jurnal Theologia, Volume 22, No. 1, Januari 2011, (Semarang: Fak. Ushuluddin IAIN Walisongo, 2001), h. 25-26. 
penting untuk segera dilakukan penggalian secara komprehensif tentang konsep Islam yang berkaitan dengan lingkungan serta implementasi dan revitalisasinya. Konsep Islam ini kemudian digunakan sebagai dasar pijakan (moral dan spiritual) dalam upaya penyelamatan lingkungan.

Dengan latar belakang di atas, penyusun akan mengurai tentang etika pelestarian lingkungan hidup dalam Islam dengan fokus kajian hubungan isu lingkungan dengan etika global, ragam teori ekologi, serta etika pelestarian lingkungan hidup dalam Islam.

\section{PEMBAHASAN}

\section{Etika Global dan Isu Lingkungan}

Globalisasi pada prinsipnya mengacu pada perkembanganperkembangan yang cepat di dalam teknologi komunikasi, transformasi, informasi yang bisa membawa bagian-bagian dunia yang jauh (menjadi hal-hal) yang bisa dijangkau dengan mudah. ${ }^{6}$

Dalam era globalisasi ini berarti terjadi pertemuan dan gesekan nilai-nilai budaya dan agama di seluruh dunia yang memanfaatkan jasa komunikasi, transformasi dan informasi hasil modernisasi teknologi tersebut. Pertemuan dan gesekan ini akan menghasilkan kompetisi liar yang berarti saling dipengaruhi (dicaplok) dan mempengaruhi (mencaplok): saling bertentangan dan bertabrakan nilai-nilai yang berbeda-beda yang akan menghasilkan kalah atau menang; atau saling bekerja sama yang akan menghasilkan sintesa dan antitesa. ${ }^{7}$

Cara pandang ilmu pengetahuan dan teknologi modern pada dasarnya adalah sekuler, mekanistis, dan reduksionistis. Sekuler karena ilmu pengetahuan tidak lagi didasarkan pada prinsi-prinsip apriori yang diterima benar dengan sendirinya, tetapi didasarkan pada pengamatan panca indra dan metode induksi. Mekanistis karena seluruh alam semesta dan juga manusia, terutama dilihat sebagai semacam mesin yang berfungsi secara mekanistis dan bisa dianalisis dan diprediksikan secara terpisah lepas dari keseluruhan yang membentuknya. Reduksionis

${ }^{6}$ A. Qodri Azizy, Melawan Globalisasi, Reinterpretasi Ajaran Islam, cet. IV, (Yogyakarta: Pustakapelajar, 2004) ,h. 19.

${ }^{7}$ Ibid.,h. 20 
karena realitas alam semesta termasuk manusia, dilihat secara reduksionis dari satu aspek semata saja tanpa melihat keterkaitan yang lebih komprehensif dan holistik di antara berbagai aspek.

Kita telah mengalami kemajuan teknologi yang lebih besar dari sebelumnya, namun kita masih saja menyaksikan bahwa kemiskinan, kelaparan, kematian anak-anak, pengangguran, kesengsaraan dan kehancuran alam semakin meluas tidak berkurang bahkan malah meningkat. Banyak orang terancam dengan kehancuran ekonomi, kekacauan sosial, marginalisasi politik, bencana ekologi dan kehancuran moral. ${ }^{8}$

Proyek modernisme tidak saja gagal mencapai sasarannya, tetapilebih dari itu telah melahirkan berbagai konsekuensi buruk bagi kehidupan manusia dan alam pada umumnya. Oleh karena itu muncullah postulat baru yang menawarkan solusi atas kegagalan modernisme dalam berelasi terhadap dunia yaitu postmodernisme.

Postmodernisme lahir di Eropa dan menjalar di Amerika, serta kemudian ke seluruh dunia bagai air yang tak terbendung. Pada prinsipnya, gerakan ini menggugat "proyek" modernisme yang dinilai telah gagal mencapai sasarannya. Moderenisme tampil dalam sejarah sebagai kekuatan progresif yang menjanjikan pembebasan manusia dari belenggu keterbelakangan dan irrasionalitas. ${ }^{9}$

Melihat begitu banyaknya konsekuensi buruk yang ditimbulkan oleh proyek modernisme, tidak berlebihan jika dikatakan bahwa manusia modern telah membakar tangannya dengan api yang telah dinyalakan sendiri. Demikianlah, dunia belakangan ini ditandai dengan pembicaraan tentang apa yang disebut krisis global. Manusia dewasa ini makin sadar bahwa seluruh krisis di bumi ini tidak hanya disebabkan oleh alasan material, melainkan justru lebih pada sebab-sebab yang bersifat transendental; sebab sebab cara pandang manusia terhadap alam. Dunia modern sekarang ini tidak lagi memiliki horizon spiritual. Bahkan Schumacher ${ }^{10}$ dengan tegas menyatakan bahwa kegagalan

8 Hans Kung dan Karl-JosepKushel, Etika Global(A Global Ethic: The Declaration of The Parliament of The World's Religions), terj. Ahmad Murtajib (Yogyakarta: PustakaPelajar, 2000), h. 13.

9 Alwi Shihab, Islam Inklusif, h, 50-51.

${ }^{10}$ Lihat, E.F. Schumacher, Keluar dari Kemelut: Sebuah Peta Pemikiran Baru, terj. Mochtar Pattobing, (Jakarta: LP3ES, 1981), h. 160. 
proyek modernisme yang ditandai dengan berbagai krisis itu adalah karena tidak disertainya agama di dalamnya. ${ }^{11}$

Berangkat dengan argumentasi ini, tidak berlebihan jika berharap kepada agama untuk dijadikan sebagai salah satu sumber etik mayoritas manusia dalam mengatasi berbagai macam krisis akibat dampak dari modernisasi. Cara pandang tersebut yang pada akhirnya mempertemukan para tokoh agama seluruh dunia hadir dalam pertemuan Dewan Parlemen Agama-agama Dunia, pada 28 Agustus 1993. Dalam pertemuan tersebut menghasilkan sebuah deklarasi yaitu Declaration Toward a Global Ethic atau Deklarasi Menuju Etika Global.

Inti dasar dari etika global adalah ilmu pengetahuan yang disertai kebijaksanaan, teknologi yang disertai kekuatan spiritual, industri yang dibarengi dengan ekologi dan demokrasi yang disertai moral. ${ }^{12}$

Dalam pendahuluan deklarasi, kutukan diarahkan pada perusakan ekosistem bumi, ekonomi yang tidak berkeadilan yang mengakibatkan kemiskinan dan kelaparan, kekacauan bangsa-bangsa, pelecehan keadilan, anarki yang berlangsung di masyarakat, agresi dan kebencian atas nama agama. ${ }^{13}$ Dalam Declaration Toward a Global Ethic kalimat pertama yang dinyatakan adalah masing-masing dari kami bergantung kepada kebaikan semuanya, karena kami menghormati komunitas makhluk hidup, umat manusia, binatang, tumbuh-tumbuhan dan bagi pemeliharaan bumi, udara, air dan tanah. ${ }^{14}$

Dunia yang semakin kapitalis secara langsung ataupun tidak langsung mempengaruhi cara pandang manusia yang eksploitatif terhadap alam. Alam dipandang sebagai produsen yang harus diperkosa untuk memenuhi kebutuhan ekonomi manusia. ${ }^{15}$

${ }^{11}$ A. Solikhan, Etika Global dan Masa Depan Umat Manusia, (Semarang: Jurnal Penelitian Walisongo, 2003), h, 74.

${ }^{12}$ Lihat Th. Sumartana. "Kata Pengantar" dalam Hans Kung dan Karl-Josep Kushel. Etika Global, h. xvi.

${ }^{13}$ Hans Kung dan Karl-Josep Kushel, Etika Global, h.1-2

${ }^{14}$ Ibid., h. 3-4.

${ }^{15} \mathrm{http}$ ://ideas.repec.org/p/rpi/rpiwpe/0501.html Quentin M. Duroy, The Determinants of Environmental Awareness and Behavior, 2005, h. 2. 


\section{Etika Lingkungan}

Dalam sejarah perkembangan pemikiran di bidang etika lingkungan, dapat dibedakan beberapa teori etika lingkungan yang dapat menentukan pola perilaku manusia kaitannya dengan alam. Adapun teori tersebut adalah antroposentrisme, biosentrisme, ekosentrisme, hak asasi alam dan Eko-feminisme.

\section{Antroposentrisme}

Teori lingkungan ini memandang manusia sebagai pusat dari sistem alam semesta. Manusia dan kepentingannya dianggap yang paling menentukan dalam tatanan ekosistem dan dalam kebijakan yang diambil dalam kaitan dengan alam, baik secara langsung maupun secara tidak langsung. Nilai tertinggi adalah manusia dan kepentingannya, dimana nilai dan prinsip moral hanya berlaku bagi manusia demikian juga etika. ${ }^{16}$

Antroposentrisme selain bersifat antroposentris, juga sangat instrumentalistik. Artinya pola hubungan manusia dan alam dilihat hanya dalam relasi instrumental. Alam ini sebagai alat bagi kepentingan manusia, sehingga apabila alam atau komponennya dinilai tidak berguna bagi manusia maka alam akan diabaikan (bersifat egois).

Karena bersifat instrumentalik dan egois maka teori ini dianggap sebagai sebuah etika lingkungan yang dangkal dan sempit. Teori ini dianggap sebagai salah satu penyebab, bahkan penyebab utama, dari krisis lingkungan yang terjadi. Teori ini menyebabkan manusia mengeksploitasi dan menguras alam semesta demi memenuhi kepentingan dan kebutuhan hidupnya dan tidak peduli terhadap alam.

\section{Biosentrisme}

Teori lingkungan ini memandang setiap kehidupan dan makhluk hidup mempunyai nilai dan berharga pada dirinya sendiri. Tidak hanya manusia yang mempunyai nilai, alam juga mempunyai nilai pada dirinya sendiri lepas dari kepentingan manusia. Biosentrisme menolak argumen antroposentrisme, karena yang menjadi pusat perhatian dan yang dibela oleh teori ini adalah kehidupan, secara

\footnotetext{
${ }^{16}$ Sonny Keraf, Etika Lingkungan, (Jakarta: Penerbit Buku Kompas, 2002), h. 33-49.
} 
moral berlaku prinsip bahwa setiap kehidupan di muka bumi ini mempunyai nilai moral yang sama sehingga harus dilindungi dan diselamatkan. ${ }^{17}$

Konsekuensinya, alam semesta adalah sebuah komunitas moral, baik pada manusia maupun pada makhluk hidup lainnya. Manusia maupun bukan manusia sama-sama memiliki nilai moral, dan kehidupan makhluk hidup apapun pantas dipertimbangkan secara serius dalam setiap keputusan dan tindakan moral, bahkan lepas dari perhitungan untung-rugi bagi kepentingan manusia.

\section{Ekosentrisme}

Teori ini secara ekologis memandang makhluk hidup (biotik) dan makhluk tak hidup (abiotik) lainnya saling terkait satu sama lain. Etika diperluas untuk mencakup komunitas ekologis seluruhnya, baik yang hidup maupun tidak. Kewajiban dan tanggung jawab moral tidak hanya dibatasi pada makhluk hidup. ${ }^{18}$

Salah satu versi ekosentrisme adalah Deep Ecology. Deep Ecology diperkenalkan oleh Arne Naess (filsuf Norwegia) tahun 1973 dalam artikelnya "The Shallow and the Deep, Long-range Ecological Movement: A summary."Deep Ecology menuntut suatu etika baru yang tidak berpusat pada manusia, tetapi berpusat pada makhluk hidup seluruhnya dalam kaitannya dengan upaya mengatasi persoalan lingkungan hidup.

\section{Eko-feminisme}

Eko-feminisme menawarkan sebuah telaah kritis, atas akar dari semua krisis lingkungan dewasa ini. Dalam kerangka ekologi, Eko-feminisme adalah sebuah teori dan gerakan etika yang, sebagaimana halnya biosentris dan ekosentris, ingin mendobrak etika antroposentrisme yang lebih mengutamakan manusia dari pada alam. Bahkan secara lebih khusus, yang dilawan Eko-feminisme bukan hanya sekedar antroposentris, akan tetapi teori lingkungan yang berpusat pada laki-laki yang selama ini mempunyai cara pandang dominasi dan subordinasi, hirarkis yang menempatkan status bertingkat dan dualisme nilai untuk memberikan nilai tinggi dan rendah. Dalam hal ini, Eko-feminisme adalah sebuah teori etika

\footnotetext{
${ }^{17}$ Ibid., h. 49-75

${ }^{18}$ Ibid., h. 75-103
} 
lingkungan yang menganut pandangan yang integral, holistik dan intersubjektif yang memandang kehidupan manusia dan masyarakat sebagai satu kesatuan integral dari dan berada dalam satu kesatuan dengan alam semesta seluruhnya. ${ }^{19}$

\section{Etika Lingkungan Islami}

Seyyed Hossein Nasr dalam Religion and the Order of Nature menyatakan bahwa bumi ini sedang meradang dan berdarah. Menurutnya, pangkal tolaknya adalah kurangnya kearifan (moral) dalam memperlakukan alam. Baginya, agama memiliki peran penting dalam membantu mengatasi masalah lingkungan yang krusial ini. Bagi Nasr, alam adalah simbol Tuhan. Pemahaman terhadap simbol ini akan mengantarkan pada eksistensi dan keramahan Tuhan. Merusak alam sama dengan "merusak" Tuhan. ${ }^{20}$

Agama Islam adalah agama yang dipeluk oleh sejumlah besar penduduk bumi. Dapat dibayangkan betapa besar dampak kebaikannya terhadap lingkungan jika seluruh penganut agama Islam memiliki kesadaran yang sama untuk memberikan perhatian yang serius terhadap pelestarian lingkungan. Maka dari itu, kiranya saat ini para tokoh Islam sangat perlu menggali lebih jauh unsur-unsur keagamaan mereka, apakah unsur teologis, fiqih atau unsur-unsur ajaran lain ${ }^{21}$ yang dapat membantu dan memotivasi masyarakat agar mencintai dan bertanggung jawab terhadap lingkungan. ${ }^{22}$

Meskipun secara ideal, agama Islam sebagai suprastruktur ideologis masyarakat muslim, diyakini memiliki nilai-nilai yang cukup intens dalam rekayasa lingkungan, namun secara faktual tampilan perilaku ekologis dipermukaan masyarakat Islam tampak masih beragam. Ada

${ }^{19}$ Ibid., h. 103-123

20 Seyyed Hossein Nasr, Religion and the Order of Nature, (New York: Oxford University Press, 1996), h. 3.

${ }^{21}$ Pada awal tahun 2011, terbit sebuah buku yang mengkaji etika lingkungan dari ranah sufi yang berjudul Eko-Sufisme Konsep, Strategi dan Dampak karya Suwito NS, sebagai hasil dari Disertasinya.

${ }^{22}$ Aang Kunaepi, "Konservasi Alam dalam Pandangan Islam (Sebuah Upaya untuk Mereduksi Kerusakan Alam)", Jurnal Pemikiran Agama untuk Pemberdayaan Dimas, Vol. 11, (Semarang: PPM IAIN Walisongo, 2011), h.53-54. 
yang cukup tinggi, sedang dan rendah. Bahkan kategori yang disebut terakhirlah yang mewarnai mayoritas masyarakat muslim. ${ }^{23}$

Dalam lektur Islam, konsep lingkungan diperkenalkan oleh alQur'an dengan beragam term. Yaitu term seluruh spesies (al-âlamîn), ruang dan waktu (al-samâ'), bumi (al-ardl), dan lingkungan (al-bîah). ${ }^{24}$

Menurut MS Ka'ban dalam berinteraksi dengan alam serta lingkungan hidup itu, manusia mengemban tiga amanah dari Allah. Pertama, al-intifấ. Allah mempersilahkan kepada umat manusia untuk mengambil manfaat dan mendayagunakan hasil alam dengan sebaikbaiknya demi kemakmuran dan kemaslahatan. Kedua, al-i'tibâr. Manusia dituntut untuk senantiasa memikirkan dan menggali rahasia di balik ciptaan Allah seraya mendapat pelajaran dari berbagai kejadian dan peristiwa alam. Ketiga,al-ishlâh. Manusia diwajibkan untuk terus menjaga dan memelihara kelestarian lingkungan itu. ${ }^{25}$

Pendapat ini cukup representatif sebagai kerangka argumentasi dalam pelestarian lingkungan dalam Islam, namun demikian masih terdapat khazanah intelektual Islam yang dapat ditampilkan sebagai upaya memperlengkap ranah kajian ekologi Islami, yaitu:

\section{Eko-teologi}

Masalah konservasi lingkungan dalam konteks ini ditatap dalam kerangka teologi yang kemudian dikenal dengan istilah ekoteologi. Meskipun teologi pada dasarnya merupakan disiplin yang menyajikan masalah keimanan pada Tuhan dengan porsi-porsi yang koheren namun ia terikat oleh konteks lingkungan (kosmos) dan manusia. Hal ini sejalan dengan tema besar al-Qur'an yang menurut Fazlur Rahman berbicara pada tiga tema besar itu, yakni, Allah, alam semesta dan manusia. Karena itu, bahasan-bahasan teologi di sini dibatasi pada pengertian di atas dan tidak diletakkan dalam kerangka diskursus ilmu kalam. ${ }^{26}$

${ }^{23}$ Mujiono Abdullah, Agama Ramah Lingkungan Perspektif al-Qur'an, (Jakarta: Paramadina, 2001), h. 6.

${ }^{24}$ Ibid., h. 33-51.

${ }^{25}$ MS. Ka'ban, "Pengelolaan Lingkungan Hidup dalam Perspektif Islam", dalam Jurnal Millah, vol. VI. No. 2, (Yogyakarta: MSI PPS UII, 2007), h. 5.

${ }^{26}$ Mudhofir Abdullah, "Argumentasi Konservasi Lingkungan dalam Perspektif Ekoteologi," dalam Jurnal Theologia, Volume 22, No. 1, Januari 2011, (Semarang: Fak. Ushuluddin IAIN Walisongo, 2001), h. 25-26. 
Eko-teologi adalah bentuk teologi konstruktif yang membahas interrelasi antara agama dan alam, terutama dalam menatap masalah-masalah lingkungan. Secara umum eko-teologi berangkat dari suatu premis bahwa ia ada karena adanya hubungan antara pandangan dunia keagamaan manusia dan degradasi lingkungan. ${ }^{27}$

Masyarakat memerlukan eko-teologi bukan hanya sebagai cara untuk mempertahankan peradaban, tetapi sebagai tool untuk menyembuhkan akar-akar krisis ekologi yang tidak lagi terletak pada teknologi tapi pada keimanan dan struktur nilai manusia yang mengendalikan teknologi. ${ }^{28}$

Konsep tauhid pada awalnya berarti mengesakan Allah, namun dalam perkembangannya digunakan untuk konsep-konsep sosial, budaya dan akhirnya lingkungan hidup. Sebagai sebuah konsep inti di dalam Islam, tauhid merupakan world view, suatu way of life yang memandang alam semesta sebagai berasal dari Allah, kembali kepada-Nya dan berpusat di sekitar-Nya. ${ }^{29}$

Dalam hal lingkungan, al-Qur'an antara lain menunjukkan konsep taskhîr dan istikhlâf sebagai acuan dalam membina interaksi manusia dengan alam. Taskhîr berarti manusia diberi wewenang untuk menggunakan alam raya guna mencapai tujuan penciptaannya sesuai dengan tuntutan ilahi. Al-Qur'an menegaskan bahwa Allah menciptakan alam raya dan penghuninya dengan tujuan tertentu sebagaimana dalam QS. 38:27.30

Adapun istikhlâf berkaitan dengan penugasan Allah kepada manusia sebagai khalifah bumi. Segala anugerah, kekayaan, bahkan nyawa sekalipun, merupakan pemilikan sementara yang dipercayakan selama hidup di bumi. Pemberian kepercayaan Tuhan antara lain menggariskan bahwa hubungannya dengan alam tidak bersifat menaklukkan, akan tetapi bertujuan untuk menciptakan interaksi harmonis dan kebersamaan dalam ketaatan kepada Allah. Alam raya sejajar dan senasib dengan manusia dalam ketundukan kepada Allah. Alam pun ikut mengagungkan Tuhan, walaupun

\footnotetext{
27 Ibid., h. 27.

${ }^{28}$ Ibid., h. 29

${ }^{29} \mathrm{Ibid}$.

${ }^{30}$ Alwi Shihab, Islam Inklusif, h, 50-51.
} 
manusia tidak memahaminya (QS. 57: 1, 59: 61, 13: 13, dan 17; 44). Bahkan binatang melata, unggas yang terbang dan makhluk yang di air, kesemuannya merupakan komunitas seperti kalian (umamun amtsâlukum), seru al-Qur'an QS. 6: 38). ${ }^{31}$

Misi utama manusia adalah misi moral dan intelektual. Dia merupakan jembatan kosmis tempat lewat kehendak Allah dalam totalitas dan waktu dan menjadikannya aktual. Dengan dilengkapi akal dan kemampuan mengkonseptualisasikan, manusia diberi petunjuk melalui wahyu Tuhan dalam terma-terma keutamaan moral. Alam ini baginya adalah wahana ujian oleh karena itu manusia memegang tanggung jawab kekhalifahan dan harus bertanggung jawab di hadapan Allah Swt. ${ }^{32}$

Menurut Amin Syukur seluruh dasar ekologi Islam benar-benar terletak pada gagasan al-Qur'an tentang kekhalifahan dan amânah. Alam adalah milik Tuhan diberikan kepada manusia semata-mata sebagai sebuah amânah. Hak manusia untuk menguasai alam hanyalah dengan kebijaksanaan teomorfisnya, bukan memberontak menentang Tuhan. ${ }^{33}$

Sebagai khalifah, manusia mempunyai tugas kepemimpinan telah menyandang beberapa kualitas tertentu sebagaimana diisyaratkan dalam al-Qur'an. Tugas-tuganya diantaranya adalah, memakmurkan bumi, menegakkan kebenaran dan keadilan, motivator dan dinamisator dalam kebaikan. ${ }^{34}$

Hubungan antara Allah, manusia sebagai khalifah, dan alam adalah merupakan hubungan segi tiga dimana Allah merupakan puncaknya. Dalam kedudukan yang seperti ini, maka pengelolaan alam oleh manusia tidak akan bersifat antroposentris, artinya nilai mempertahankan, memelihara, mengembangkan dan meningkatkan kualitas hidupnya tidak akan mengarah pada diri sendiri, tetapi bersama alam dan Tuhan. Hubungan antara khaliffah, alam dan Tuhan dengan meletakkan manusia pada titik puncaknya akan mengakibatkan eksploitasi alam yang semena-mena yang akan

\footnotetext{
${ }^{31}$ Ibid., 164-165

${ }^{32}$ Amin Syukur, Tasawuf Sosial, (Yogyakarta: Pustaka Pelajar, 2004), h. 152-153.

${ }^{33}$ Ibid, h. 153

${ }^{34}$ Ibid, h. 153-154.
} 
menghancurkan alam itu sendiri. Hubungan manusia (khaliffah), alam dan Tuhan dalam sebuah segi tiga dimana Tuhan pada titik puncaknya akan membuahkan pemanfaatan alam yang teistik, yakni hubungan manusia dengan alam bukan hubungan antara penakluk dan yang ditaklukkan, atau antara tuan dan hamba, tapi hubungan kebersamaan dalam ketundukan kepada Allah swt. Pengelolaan alam yang teistik ini akan menghindarkan tindakan penguasa tanpa batas terhadap alam, karena alam dan manusia adalah dalam garis horizontal yang sama, yakni sama-sama sebagai makhluk Tuhan. ${ }^{35}$

Berdasarkan petunjuk al-Qur'an di atas jelas bahwa Islam sangat memperhatikan keserasian hubungan antara manusia dan alam. Ini ditunjukkan agar tidak terjadi gangguan dalam sistem ekologi. Sebaliknya, kecaman terhadap perusakan di bumi berulang kali dijumpai dalam (QS. 28: 77, 2: 60).

\section{Fiqh Lingkungan}

Fiqh yang berarti juga sebagai sistem pemikiran hukum Islam dapat memberikan kepastian bagi mereka yang meyakininya. ${ }^{36}$ Dengan adanya kepastian tersebut orang atau umat Islam menjadi tidak ragu-ragu lagi bahwa masalah lingkungan hidup adalah masalah yang memang penting untuk diperhatikan. Selanjutnya, kepastian tersebut dapat diharapkan menjadi suatu sumber motivasi yang sangat kuat bagi umat Islam khususnya untuk semakin peduli terhadap lingkungan hidup.

Fiqh lingkungan merupakan terobosan baru bagi upaya konservasi dan restorasi lingkungan hidup dengan perspektif keagamaan. Perspektif ini sekaligus menegaskan akan pentingnya pendekatan agama termasuk produk hukumnya, dalam rangka konservasi dan restorasi lingkungan hidup sebagai supplement bagi pendekatan disiplin ilmu lain yang telah ada.

Dalam konteks hukum Islam, pelestarian lingkungan hidup, dan tanggung jawab manusia terhadap alam banyak dibicarakan. Hanya saja, dalam berbagai tafsir dan fiqh, isu-isu lingkungan hidup hanya disinggung dalam konteks generik dan belum spesifik sebagai

${ }^{35}$ Ibid., h. 155

${ }^{36}$ Budhy Munawar-Rachman (ed), Kotekstualisasi Doktrin Islam Dalam Sejarah, (Jakarta: Penerbit Paramadina, 1995), h. 331. 
suatu ketentuan hukum yang memiliki kekuatan. Fiqh-fiqh klasik telah menyebut isu-isu tersebut dalam beberapa bab yang terpisah dan tidak menjadikannya buku khusus. Ini bisa dimengerti karena konteks perkembangan struktur masyarakat waktu itu belum menghadapi krisis lingkungan sebagaimana terjadi sekarang ini.

Melihat situasi modern saat ini yang dengan jelas-jelas ditandai oleh kerusakan lingkungan hidup yang begitu dahsyat, rasanya fiqh tentang lingkungan hidup perlu dikembangkan terus-menerus agar dapat menjawab kebutuhan zaman yang semakin menekankan pentingnya perlindungan terhadap lingkungan hidup. Dengan kata lain, pengembangan fiqh lingkungan hidup kini bisa menjadi suatu pilihan penting di tengah krisis-krisis ekologis yang secara sistematis disebabkan oleh keserakahan manusia dan kecerobohan penggunaan teknologi.

Kerusakan alam akan berdampak pada kemiskinan dan sebaliknya, pelestarian alam dan lingkungan akan berimplikasi positif pada kesejahteraan hidup dan peningkatan ekonomi. Oleh karena itu bagi umat Islam merupakan kewajiban mempertahankan hidup dan kehidupan, sehingga jika tidak ada wali , pernikahan tidak sempurna, maka keberadaan wali dalam pernikahan menjadi wajib. Ini berarti melestarikan kehidupan dan alam seisinya demi kelestarian hidupnya juga menjadi wajib adanya. Logika ini sejalan dengan kaidah ushul, mâ lâ yatimmu al-wâjib illâ bihî fa huwa wâjib. ${ }^{37}$

K.H. Sahal Mahfudz berpendapat bahwa dalam penggunaan alam harus didasarkan aspek manfaah dan mafsadah, untuk menunjang kebutuhan dan kehidupan. Pemenuhan kebutuhan itu harus sesuai dengan skala prioritas dan diarahkan kepada kepentingan hidup bersama, tidak boleh menuruti kepentingan pribadi atau kelompok. Pertimbangan kolektifitas itu dimaksudkan agar dalam pengelolaan alam dapat harmonis dan seimbang serta tetap berpijak pada moral dan etika. ${ }^{38}$

\section{Eko-Sufisme}

Dalam konteks ekologi, pembicaraan dalam ekosistem seringkali lebih fokus dalam dimensi potensi alam sebagai produsen dan konsumen. Penyedia pangsa dan pemangsa. Dalam hal ini, termasuk

${ }^{37}$ Sumanto al-Qurtuby, K.H. Sahal Mahfudz, Era Baru Fiqih Indonesia, (Yogyakarta: Cermin, 1999), h. 96.

${ }^{38}$ Ibid., h. 97 
mineral adalah produsen/konsumen tanaman. Pembicaraan tentang etika, estetika, bahkan puitika relasi dalam ekosistem luput dalam pembicaraan ekologi. ${ }^{39}$

Sufisme di dalamnya membicarakan etika memandang perlu berkolaborasi dengan ekologi sebagai kajian interdisipliner. Sufisme (sebagai dimensi mistik Islam) menitikberatkan pada pola relasi yang etis dan estetik antara manusia dan Tuhan, serta antara manusia dengan ekosistem lainnya. Dalam konteks ini, Islam sebagai basis sufisme memandang bahwa semua ciptaan mempunyai manfaat dan diadakan tanpa kesia-siaan dan bahkan bertasbih. ${ }^{40}$

Pernyataan bahwa semua makhluk bertasbih kepada Allah adalah merupakan premis kebenaran. Kenyataan ini adalah realita metafisik (ghâib) yang tidak diterima oleh tradisi keilmuan Barat. Jika demikian halnya maka bebatuan, daun, tumbuhan, hewan, bahkan nasi maupun piringnya bertasbih. Secara ekosistem, diantara mereka adalah produsen (penyedia makan), bagi yang lainnya. ${ }^{41}$

Dalam tradisi sufi, relasi ekosistem bukan hanya berlaku hukum produsen dan konsumen sebagaimana pada ekologi. Tetapi sufisme justru memiliki pandangan yang lebih maju dan holistik. Alam, dalam tradisi sufi dapat berfungsi sebagai âyah (tanda kebesaran Allah), media untuk mendekatkan diri (qurbah) dan (syukr), piranti pembelajaran (mendapatkan kearifan), pemanis (zînah) dan pemenuhan kebutuhan (konsumsi). ${ }^{42}$

Menurut Seyyed Hosen Nasr sebagaimana dinukil oleh Suwito bahwa kosmologi tradisional dalam sufisme mengijinkan manusia memikirkan alam sebagai hal yang sakral. Alam dipandang sebagai perspektif pengetahuan "suci" dengan menggunakan kesucian mata hati (intuisi). Proses yang demikian melahirkan pengetahuan bahwa alam adalah teofani Tuhan. Alam merupakan refleksi keilahiahan dalam cermin bentuk-bentuk ciptaan. ${ }^{43}$

39 Suwito NS, Eko-Sufisme, Konsep, Strategi, dan Dampak, cet. II (Purwokerto: STAIN Press Purwokerto, 2011), h. 43.

${ }^{40} \mathrm{Ibid}$.

${ }^{41}$ Ibid.

${ }^{42}$ Ibid., h, 43-44

${ }^{43}$ Ibid., h, 45 
Eko-sufisme dapat berarti sufisme berbasis ekologi, artinya kesadaran spiritual yang diperoleh dengan cara memaknai interaksi antara sistem wujud terutama pada lingkungan sekitar. Lingkungan adalah media atau sarana untuk dzikir dan sampai (wushôl) kepada Allah. Alam adalah sumber kearifan, sehingga harus diberlakukan dengan bijaksana. Dalam kontek ekologi, kerusakan/merusak alam sama dengan merusak diri sendiri dan generasi. Sementara dalam eko-sufisme dapat dikatakan bahwa merusak alam sama dengan merusak kehidupan sekaligus merusak sarana ma'rifah. ${ }^{44}$

Etika eko-sufisme mendorong perilaku manusia hidup selaras dengan Allah dan alam. Sistem etika ini kemudian melahirkan keindahan. Kedua aspek ini kemudian menjadi atribut diri dan sosial sehingga eko-sufisme memiliki corak tersendiri dengan sufi lain. ${ }^{45}$

Menurut pandangan al-Qur'an, manusia kaitannya dengan lingkungan hidup memiliki tanggung jawab dan memikul amanat Allah. Amanat ini mencakup kewajiban dan tanggung jawab manusia terhadap Allah, sesamanya dan terhadap alam. Amanat itu akan dapat dilaksanakan dengan sebaik-baiknya, manakala manusia terlebih dahulu mengenal Allah (ma'rifah Allah), mengenal diri sendiri (ma'rifah al-nafs), mengenal sesama manusia (ma'rifah alnâs), dan mengenal alam (ma'rifah al-kaun). ${ }^{46}$

Manusia dalam konteks ma'rifah al-kaun, dalam mengelola alam menurut pandangan al-Qur'an bukanlah akibat dari kekuatan yang dimilikinya, tetapi akibat anugerah Allah (QS. 14; 32). Dengan demikian berarti manusia dalam mengembangkan dan mengelola alam senantiasa bergantung pada hukum-hukum yang terdapat dalam sunnah Allah. Sehingga dalam hal ini hubungan antara manusia dengan alam bukan merupakan hubungan antara penakluk dan yang ditaklukkan, atau antara tuan dengan hambanya, tetapi hubungan kebersamaan dalam ketundukan kepada Allah swt. ${ }^{47}$

Paparan tentang eko-religius di atas yang di dalamnya terdapat ranah kajian eko-teologi, fiqh lingkungan dan eko-sufisme

\footnotetext{
${ }^{44}$ Ibid.,h, 47

${ }^{45}$ Ibid., h, 48

${ }^{46}$ Amin Syukur, Tasawuf Sosial, h. 157

${ }^{47}$ Ibid.,h. 158-159.
} 
merupakan upaya para ulama' Islam dalam mensinergiskan ajaran Islam dengan teologi lingkungan hidup melalui reinterpretasi teks untuk merekonstruksi cara pandang dan perilaku manusia dalam berelasi dengan lingkungan hidup. Interpretasi teks, tentunya belum mencukupi, karena perlu langkah-langkah strategis dan praktis dalam mengoperasionalisasikan hasil reinterpretasi teks tersebut. Sebagai contoh, Suwito NS dalam buku Eko-sufismenya memperlihatkan dampak ekonomi yang semakin positif dari upaya konservasi yang dilakukan. Jamaah Ilmu Giri dan Aolia Panggang yang sebelumnya dihantui dengan krisis lingkungan diantaranya berupa penggundulan hutan dan krisis air, dengan upaya konservasinya melalui pemahaman tasawuf mampu meningkatkan pendapatan ekonominya. ${ }^{48}$

\section{PENUTUP}

Eko-teologi melihat bahwa konservasi alam bukan hanya sebagai cara untuk mempertahankan peradaban, tetapi juga sebagai tool untuk menyembuhkan akar-akar krisis ekologi yang tidak lagi terletak pada teknologi tapi pada keimanan dan struktur nilai manusia yang mengendalikan teknologi.

Sementara itu, Fiqh Lingkungan berpendapat bahwa dalam penggunaan alam harus didasarkan pada aspek manfaah dan mafsadah, untuk menunjang kebutuhan dan kehidupan. Pemenuhan kebutuhan itu harus sesuai dengan skala prioritas dan diarahkan kepada kepentingan hidup bersama, tidak boleh menuruti kepentingan pribadi atau kelompok. Pertimbangan kolektifitas itu dimaksudkan agar dalam pengelolaan alam dapat harmonis dan seimbang serta tetap berpijak pada moral dan etika.

Selain itu, Eko-sufisme juga menegaska bahwa kesadaran spiritual yang diperoleh dengan cara memaknai interaksi antara sistem wujud terutama pada lingkungan sekitar. Lingkungan adalah media atau sarana untuk dzikir dan sampai (wushûl) kepada Allah. Alam adalah sumber

${ }^{48}$ Sebagai perbandingan penghasilan ketika lahan tandus ditanami singkong dan kayu jati. Saat lahan ditanami singkong pertahun, petani mendapatkan penghasilan sekitar Rp. 3.500.000,-, namun ketika petani menanam jati yang dianggap sebagai celengan pendapatan pertahun diperkirakan mencapai Rp. 35.000.000,-. LihatSuwito NS, Eko-Sufisme, Konsep, Strategi, h. 223-225. 
Asy-Syari'ah, Volume 5, Nomor 2, Juni 2019

kearifan, sehingga harus diberlakukan dengan bijaksana. Merusak alam sama dengan merusak kehidupan sekaligus merusak sarana ma'rifah.

Dalam berinteraksi dengan alam serta lingkungan hidup, manusia mengemban tiga amanah dari Allah. al-intifầ' al-i'tibâr, dan al-ishlâh. 


\section{DAFTAR PUSTAKA}

Abdullah, Mudhofir, "Argumentasi Konservasi Lingkungan dalam Perspektif Eko-teologi”, dalam Jurnal Theologia, Volume 22, No. 1, Januari 2011, Semarang: Fak. Ushuluddin IAIN Walisongo.

Abdullah, Mujiono, Agama Ramah Lingkungan Perspektif al-Qur'an, Jakarta: Paramadina, 2001.

Azizy, A. Qodri, Melawan Globalisasi, Reinterpretasi Ajaran Islam, cet. IV, Yogyakarta: Pustaka pelajar, 2004.

Ka'ban, MS., Pengelolaan Lingkungan Hidup dalam Perspektif Islam, dalam Jurnal Millah, vol. VI. No. 2, Yogyakarta: MSI PPS UII, 2007.

Keraf, Sonny, Etika Lingkungan, Jakarta: Penerbit Buku Kompas, 2002.

Kung, Hans dan Karl-JosepKushel, Etika Global(A Global Ethic: The Declaration of The Parliament of The World's Religions), terj. Ahmad Murtajib, Yogyakarta: PustakaPelajar, 2000.

Nasr, SeyyedHossein, Religion and the Order of Natur, New York: Oxford University Press, 1996.

NS, Suwito , Eko-Sufisme, Konsep, Strategi, dan Dampak, cet. II, Purwokerto: STAIN Press Purwokerto, 2011.

al-Qurtuby, Sumanto, K.H. Sahal Mahfudz, Era Baru Fiqih Indonesia, Yogyakarta: Cermin, 1999.

Rahman, BudhyMunawar, Islam Pluralis, Jakarta: Paramadina, 2001.

Schumacher, E.F., Keluar dari Kemelut: Sebuah peta Pemikiran Baru, terj. Mochtar Pattobing, Jakarta: LP3ES, 1981.

Shihab, Alwi, Islam Inklusif, Menuju Sikap Terbuka dalam Beragama, Jakarta: Penerbit Mizan, 1999.

Solikhan, A., Etika Global dan Masa Depan Umat Manusia, Semarang: Jurnal Penelitian Walisongo, 2003.

Sudarsono, Bumiku Semakin Panas, Yogyakarta: PPLHRJ, 2008.

Syukur, Amin, Tasawuf Sosial, Yogyakarta: Pustaka Pelajar, 2004.

http://ideas.repec.org/p/rpi/rpiwpe/0501.html, 2005, Quentin M. Duroy dalam tulisannya The Determinants of Environmental Awareness and Behavior. http:// www.wwf.or.i/tentang_wwf/whoweare 